\title{
Soil quality indicators in areas with different vegetation cover in the Atlantic Forest biome, Southeastern Brazil
}

The southeast region of Brazil, in the Atlantic Forest biome, has been impacted for a long time, observing today small agricultural areas inserted in a matrix of pastures and forest fragments, the soils being highly modified due to the different forms of use they were submitted. The objective of this study was to evaluate the organic carbon content in the humic fractions on soil organic matter (SOM), the distribution of aggregates in size classes and the porosity and aggregates density variables by means of computed tomography in secondary forest, pasture and agriculture areas in Pinheiral (RJ). Three areas composed of secondary forests with different succession stages and three managed areas were evaluated: Secondary Forest (SF) Initial Stage (SFIS), Medium Stage (SFMS), Advanced Stage (SFAS), mixed managed pasture (MMP), and perennial and annual agriculture (PA and AA, respectively). Three types of samples were collected in different layers: i) deformed samples to quantify carbon in the SOM humic fractions; ii) clods for quantifying the mass of aggregates and later assessing the distribution by diameter classes; and iii) undisturbed samples collected with the aid of an acrylic cylinder to perform computed tomography (CT). Humic substances and aggregate classes below $2.0 \mathrm{~mm}$ were the attributes most influenced by the forms of use and/or vegetation cover. The CT technique proved to be efficient in the measurement of the edaphic attribute's porosity and density of the aggregates, helping in the characterization and separation of the different environments.

\section{Indicadores de qualidade do solo em áreas com diferentes coberturas vegetais no bioma Mata Atlântica, Sudeste do Brasil}

\begin{abstract}
A região sudeste do Brasil, no Bioma Mata Atlântica, vem sendo impactada por um longo tempo, observando-se hoje pequenas áreas de agricultura inseridas em uma matriz de pastagem e fragmentos florestais, sendo os solos altamente modificados em decorrência das diferentes formas de uso que foram submetidos. 0 objetivo deste estudo foi avaliar o conteúdo de carbono orgânico nas frações húmicas da matéria orgânica do solo (MOS), a distribuição dos agregados em classes de tamanho e as variáveis porosidade e densidade dos agregados por meio de tomografia computada em áreas de floresta secundária, pastagem e agricultura no município de Pinheiral (RJ). Foram avaliadas três áreas compostas por florestas secundárias com diferentes estágios de sucessão e três áreas manejadas, a saber: floresta secundária em estágio (FSE) inicial (FSEI); FSE médio (FSEM); FSE avançado (FSEA); pasto manejado misto (PMM); e agricultura perene e anual (AP e AA respectivamente). Foram coletadas três tipos de amostras em diferentes camadas: i) amostras deformadas para a quantificação do carbono das frações húmicas da MOS; ii) torrões para quantificação da massa de agregados, e posterior avaliação da distribuição por classes de diâmetro; iii) amostras indeformadas coletadas com auxílio de cilindro de acrílico para a realização da tomografia computada. As substâncias húmicas e as classes de agregados inferiores à 2,0 mm foram os atributos mais influenciados pelas formas de uso e/ou cobertura vegetal. A técnica de tomografia computada se mostrou eficiente na mensuração dos atributos edáficos porosidade e densidade dos agregados, auxiliando na caracterização e separação dos diferentes ambientes.
\end{abstract}

Palavras-chave: Fragmento florestal; Matéria orgânica do solo; Massa de agregados.

Fernado Silva Coutinho (iD

Universidade Federal Rural do Rio de Janeiro, Brasil http://lattes.cnpq.br/2215481360812474

http://orcid.org/0000-0002-3238-6759

fernando.coutinho@prodap.com.br

Luiz Alberto da Silva Rodrigues Pinto (iD Universidade Federal Rural do Rio de Janeiro, Brasil http://lattes.cnpq.br/5006918904667368 http://orcid.org/0000-0002-4369-4511 I_arodrigues@yahoo.com.br

Marcos Gervasio Pereira

Universidade Federal Rural do Rio de Janeiro, Brasil http://lattes.cnpq.br/3657759682534978 http://orcid.org/0000-0002-1402-3612 mgervasiopereira01@gmail.com
Shirlei Almeida Assunção (iD)

Universidade Federal Rural do Rio de Janeiro, Brasil http://lattes.cnpq.br/3592454473382052

http://orcid.org/0000-0002-8947-4143 shirleiaassuncao@gmail.com

\section{Silver Rodrigues Zandoná (iD}

Universidade Federal Rural do Rio de Janeiro, Brasil http://lattes.cnpq.br/3282037405035521 http://orcid.org/0000-0001-5738-885X srzandona@yahoo.com.br

\section{Fabiana da Costa Barros}

Universidade Federal Fluminense, Brasil http://lattes.cnpq.br/8890668582692634 http://orcid.org/0000-0002-9278-3721 barros.faby@hotmail.com
Renato Sinquini de Souza (iD)

Universidade Federal Rural do Rio de Janeiro, Brasil http://lattes.cnpq.br/1038563758009898

http://orcid.org/0000-0002-4170-312X renatosinquine@hotmail.com

\section{Hugo Souza Fagundes (iD)}

Universidade Federal Rural do Rio de Janeiro, Brasil http://lattes.cnpq.br/8246265276703512 http://orcid.org/0000-0003-0862-1023 hugofagundes90@gmail.com

Eduardo Henrique Silva e Souza (10)

Universidade Federal Rural do Rio de Janeiro, Brasil http://lattes.cnpq.br/7339246766448511 http://orcid.org/0000-0003-4290-8474 eduufrrj@gmail.com
Referencing this:

COUTINHO, F. S.; PINTO, L. A. S. R.; PEREIRA, M. G.; ASSUNÇÃO, S. A.; ZANDONÁ, S. R.; BARROS, F. C.; SOUZA, R. S.; FAGUNDES, H. S.; SOUZA, E. H. S.. Soil quality indicators in areas with different vegetation cover in the Atlantic Forest biome, Southeastern Brazil. Revista Ibero Americana de Ciências Ambientais, v.11, n.7, p.1-15, 2020. DOI: http://doi.org/10.6008/CBPC2179-6858.2020.007.0001 


\section{INTRODUCTION}

The Atlantic Forest Biome covers about $15 \%$ of the national territory, in 17 states, with $90 \%$ of its original area already decimated. Currently, only $12.4 \%$ of natural forests remain over 3 ha, including regenerated forests, and this percentage may increase to $26 \%$ when considering areas above 1 ha (SOS et al., 2020). In the state of Rio de Janeiro, the introduction of agricultural areas and pastures to replace native forests in this biome caused an ecosystem imbalance. The removal of the original vegetation cover and the implantation of crop cycles associated with inadequate management practices promote the disruption of the stability of the edaphic system (RICHARD et al., 2005). Such factors provide modifications in the soil physical, chemical and biological attributes, decreasing its productive capacity.

Among the attributes considered most sensitive to the action of the mentioned factors, the organic matter and the structural stability of the soil stand out. Which can be affected temporarily or permanently, depending on the set of practices that this environment is submitted to and the impacts promoted by them. Therefore, they are considered excellent indicators of soil quality.

The study of soil organic matter (SOM) in its different compartments, and humic substances and their relationship with the adopted management method, aims to develop strategies for a more sustainable use of soils. Proposing to reduce the impact of agricultural activities on the environment (GIÁCOMO et al., 2008). Among the SOM components, humic substances have a participation of approximately 85 to $90 \%$, these fractions being highly dynamic and sensitive to environmental changes. Additionally, these fractions constitute one of the main compartments responsible for the accumulation of organic carbon in the soil (PAULA et al., 2013).

Several studies have associated humic substances and other SOM fractions to the aggregate formation and stabilization processes under different vegetation coverings in the Atlantic Forest biome (GUARESCHI et al., 2014; SILVA NETO et al., 2016; FERNANDES et al., 2017; SILVA et al., 2012; 2017). Soil aggregates can be formed by physical, chemical or biological mechanisms, and are closely related to soil quality, contributing significantly to the ability to sequester carbon and maintain nutrients (FERNANDES et al., 2017). As for size, they can be sorted into three classes depending on the diameter: i) large macroaggregates (or macroaggregates), $8.0>\varnothing \geq 2.0 \mathrm{~mm}$; ii) small macroaggregates (or mesoaggregates), $2.0>\emptyset \geq 0.25 \mathrm{~mm}$; and iii) microaggregates $0.25>\varnothing \geq 0.053 \mathrm{~mm}$ (DENEF et al., 2007; COSTA JUNIOR et al., 2012; LOSS et al., 2020).

Changes in the structural stability of the soil are commonly verified from traditional analyzes, which assess the physical conditions and thus measure the environmental degradation level. With emphasis on the evaluation of aggregate stability analysis, by wet or dry methods. However, in recent years, X-ray computed tomography (CT) has been shown to be a technique that has a greater advantage over other methods. Because it is a non-invasive and non-destructive analysis of a sample, it is suitable for the analysis of relatively dense materials (WARNER et al., 1989; TOLLNER, 1991). It works as an excellent tool for the study of soils under different forms of use and management. The adaptation of the $\mathrm{CT}$ to generate soil models in third 
dimension allows quantifying characteristics such as: porosity, density, aggregation and spatial arrangement of constituents that reflect soil development (ELLIOT et al., 2007).

Based on the hypothesis that forest fragments in different succession stages and areas managed for livestock and agricultural purposes can promote changes in edaphic attributes in a different way. This study aimed to evaluate the organic carbon content in the humic fractions on SOM, the distribution of aggregates in size classes and the variables porosity and aggregates density by means of computed tomography in areas of secondary forest, pasture and agriculture in Pinheiral (RJ).

\section{MATERIALS AND METHODS}

The areas selected for the study are located in the municipality of Pinheiral, region of the Mid Paraíba do Sul Valley, State of Rio de Janeiro, Southeast Brazil (22033' to 2238' S and 435ㄱ' to 44950' W). The region is inserted in the Atlantic Forest biome of Submontane Seasonal Semidecidual Forest vegetation cover type. The altitude of the studied areas varies from 300 to $800 \mathrm{~m}$ and the local relief from wavy to strong wavy. According to Köppen, the region's climate can be classified as Cwa - temperate dry winter and rainy summer and Am - rainy tropical climate with dry winter. The annual averages of pluviometric precipitation and temperature are $1,300 \mathrm{~mm}$ and $21^{\circ} \mathrm{C}$, respectively. The soil was classified as (Inceptisol) Cambissolo Háplico Tb Distrófico típico, according to the Santos et al. (2018), one of the most prevalent classes in the highest quotas of the sub-basin (COUTINHO et al., 2017).

Three areas composed of secondary forests (with different succession stages), which composes a single forest fragment, and three managed areas were evaluated, making a total of six sample areas located in the upper third position of the slope: Secondary Forest Initial Stage (SFIS), Secondary Forest Medium Stage (SFMS), Secondary Forest Advanced Stage (SFAS), Managed Mixed Pasture with Brachiaria decumbens and Paspalum notatum (MMP), Perennial Agriculture cultivated with citrus (PA) and Annual Agriculture with rotation of corn, beans and cassava (AA) (Table 1) (Figure 1). Forest typologies were classified according to the resolution of Conselho Nacional do Meio Ambiente (CONAMA 006/1994).

In each sample area, a plot of $20 \times 20 \mathrm{~m}(0.04 \mathrm{ha})$ was delimited, and for each of them, five trenches of approximately $1 \mathrm{~m}^{3}$ were randomly opened. Three types of samples were collected: i) deformed samples in $0-5,5-10,10-20$ and $20-40 \mathrm{~cm}$ layers, which were air dried in the laboratory, ground and passed through a $2.0 \mathrm{~mm}$ mesh sieve, thus obtaining the air-dried fine earth for the characterization of chemical attributes and granulometry (TEIXEIRA et al., 2017) (Table 2) and quantification of organic carbon from humic fractions on SOM, ii) clods in 0-5 and 5-10 cm layers, for the evaluation of aggregation, and iii) undisturbed samples collected in the $0-20 \mathrm{~cm}$ layer with the aid of an acrylic cylinder (64 mm in diameter and $150 \mathrm{~mm}$ in length), to perform computed tomography (CT).

For the quantification of humic substances the differential solubility technique was used (SWIFT, 1996), with adaptation by Benites et al. (2003), obtaining organic carbon in the fulvic acid fraction (FAF), humic acid fraction (HAF) and humine fraction (HUM) (YEOMANS et al., 1988). 
Table 1: History and description of the sample studied areas under (Inceptisol) Cambissolo Háplico in Pinheiral (RJ).

\begin{tabular}{ll}
\hline Areas & Description \\
SFIS & $\begin{array}{l}\text { It presents little dense forest cover, characteristic of the initial succession stage (Brazil, 1994), originated by the use of } \\
\text { the area as spontaneous pasture until 1985, managed by annual clearings and burnings, when it was occupied by small } \\
\text { farmers who only fenced it, thus allowing forest regeneration. }\end{array}$ \\
\hline SFMS & $\begin{array}{l}\text { It is contiguous and of the same level as SFIS and until } 1985 \text { it was covered by spontaneous pasture with initial formation } \\
\text { of capoeira, being kept protected until nowadays, which allowed the typical successional development of the middle } \\
\text { stage (Brazil, 1994), characterized by a more closed shrub/tree cover than that of the initial stage. }\end{array}$ \\
\hline SFAS $\quad \begin{array}{l}\text { It presents a dense forest cover and is better structured than the previous ones, which allows to fit it in this successional } \\
\text { stage (Brazil, 1994) - the succession started after the decay of coffee cultivation in the region and constitutes the oldest } \\
\text { fragment of the lower portion of the sub-basin. }\end{array}$ \\
MMP $\quad \begin{array}{l}\text { It has been explored with spontaneous pasture since the 1950s. Since the 1990s, Brachiaria decumbens was implanted } \\
\text { and, from there, the pasture was maintained through annual mowing. With the practice of restrained burning, over the } \\
\text { years the grass known as grama-batatais (Paspalum notatum), resurfaced in this landscape, which started to coexist with } \\
\text { the introduced brachiaria. }\end{array}$ \\
PA $\quad \begin{array}{l}\text { Used as pasture until the 1990s. After that period, it was again used for agricultural activities, for the purpose of } \\
\text { subsistence (corn and beans) and is currently growing citrus in a conventional tillage system (without fertilization and } \\
\text { without liming), with periodic manual weeding. }\end{array}$ \\
AA $\quad \begin{array}{l}\text { Used for subsistence agriculture (corn, beans, cassava) for approximately } 20 \text { years. At the time of collecting the land } \\
\text { samples for the study, this area was with cassava crop. The preparation system is the conventional one (without } \\
\text { fertilization and without liming), with periodic manual weeding. }\end{array}$ \\
\hline
\end{tabular}

Source: Coutinho et al. (2017, adapted by MENEZES (2008).

As for the clods, after collection, they were dried in air and subjected to screening, using a set of 8.0 and $4.0 \mathrm{~mm}$ mesh sieves, selecting only the aggregates retained in this interval. Of these, $25 \mathrm{~g}$ were weighed to evaluate the distribution of the aggregates, later they were transferred to a set of sieves with decreasing mesh: $2.0,1.0,0.50,0.250$ and $0.105 \mathrm{~mm}$, moistened with a sprayer and subjected to vertical stirring in the Yooder apparatus (YOODER, 1936), for $15 \mathrm{~min}$. After the determined time, the material retained in each sieve was transferred to Petri dishes, and dried in an oven at $105^{\circ} \mathrm{C}$, until a constant mass was obtained. With the aggregate mass data, the distribution by classes of average diameter was evaluated (8.0-2.0; 2.0-1.0; 1.0 $0.50 ; 0.50-0.25$; and 0.25-0.105 mm).
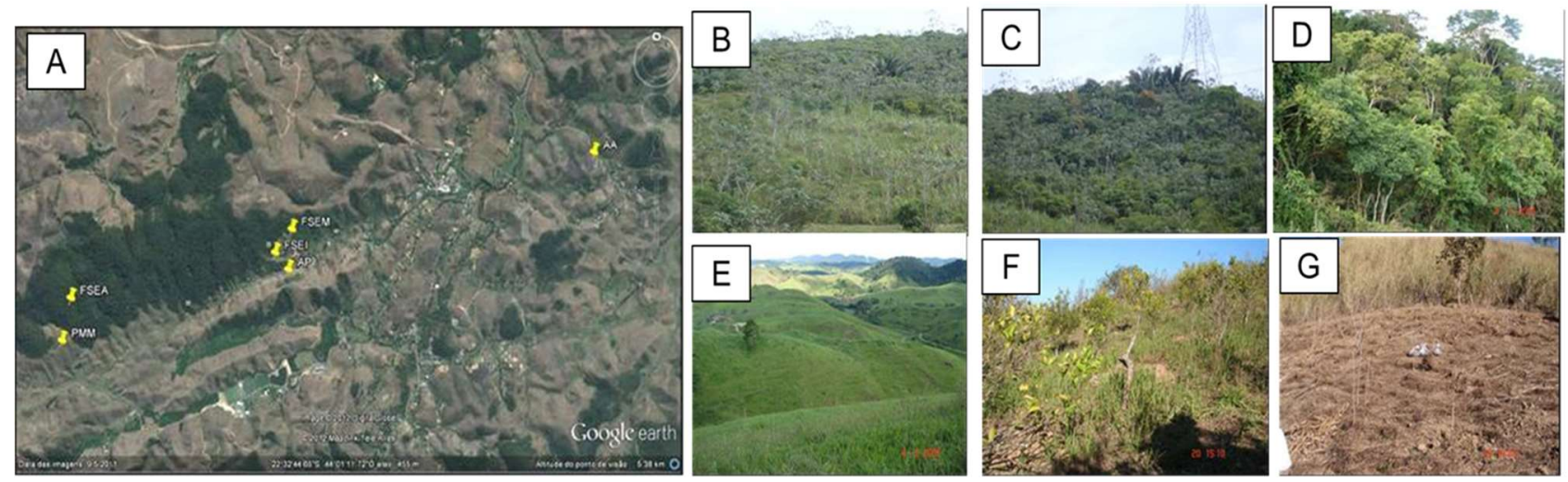

Figure 1: Location of study areas, Pinheiral (RJ) (A), where: SFIS: Secondary Forest Initial Stage (B), SFMS: Secondary Forest Medium Stage (C), SFAS: Secondary Forest Advanced Stage (D), MMP: Managed Mixed Pasture (E), PA: Perennial Agriculture (F) and AA: Annual Agriculture (G).

The acrylic cylinders containing the samples were sent to the Soil and Landscape Process laboratory at the University of Guelph, (Canada). In the laboratory, the samples were properly identified, and still inside the cylinder, they were air-dried for 72 hours so that only air and not water remain in the empty spaces, which facilitates the segmentation step. After this step, in each sample, the polyethylene support was placed for fixing the sample in the device, and the air and water patterns that were positioned so that it was between 
the X-ray source and the sample due to the attenuation of the rays. To analyze the porosity and aggregates density variables using the CT technique, the method proposed by Pavlidis et al. (1990), adapted by Elliot et al. (2007) and Schluter et al. (2010).

One of the easiest interpretations of soil sample data obtained by CT is the porous space ratio, due to the strong contrast between the solid and empty phase (TAINA et al., 2008). For each pixel within a grayscale image obtained by $\mathrm{CT}$, a number (Hounsfield Unit - HU) is assigned which is used to describe the attenuation of the $x$-rays of each voxel in a 3D model image (ELLIOT et al., 2007). The HU of a voxel, having $\mu$ as a linear attenuation coefficient, is generated using the following equation:

$$
H U=1000(\mu-\mu w) /(\mu w-\mu a)
$$

Where: $\mu \mathrm{w}$ and $\mu \mathrm{a}$ are coefficients of linear attenuation of water and air, respectively. The Hounsfield scale assigns 0 UH to distilled water and -1000 UH to air (HOUNSFIELD, 1973).

The samples were placed one by one, inside the GE Medical $\mu \mathrm{CT}$ device, model MS8X-130 of third generation, for the acquisition of images in two dimensions (2D) through the $120 \mathrm{kV}, 170 \mu \mathrm{A}, 3500 \mathrm{mS}$ protocol. The three-dimensional model of the images was reconstructed using the GE Medical software explore Reconstruction Utility (GE HEALTHCARE, 2005). The model was reconstructed with a $6 \mu \mathrm{m}$ resolution with a resulting volume of $600 \times 600 \times 600$ voxels, containing 219 million voxels. Post-reconstruction of the images was performed using the GEHC MicroView Version 2.0.29 a software to remove noise inherent in the acquired images (GE HEALTHCARE, 2005; ELLIOT et al., 2010). A Gaussian smoothing algorithm, with radius 1 , was finally applied in order to eliminate distant points within the data set to improve the contrast of the grayscale images. Subsequently, the models were reconstructed with the Imagej software, which is based on the Java language (RAJAB et al., 2008).

The segmentation model (Segmentation) used was proposed by Elliot et al. (2007) and Schluter et al. (2010), but this model alone was not sufficient to efficiently determine the threshold between porous and solid spaces. Thus, the following adaptation to the method was proposed, the image generated in the reconstruction step was exported to the imagej software and the frequency values that were imported into the spreadsheet in the Origin Pro Version 7.5 software (ORIGINLAB CORPORATION, 2004) were obtained. In this software, two peaks were defined, the first represented by voids and the second, with greater attenuation, probably by little degraded mineral material present in the soil. After the curves were identified, the equiprobability points, which occur between the intersection of the tangent of the first and the second peak (ELLIOT et al., 2007), and the maximum and minimum values for determining the threshold between solids and pores, were determined.

The original image was imported using the Imagej software, where the maximum and minimum pores and solids were defined with the values found in the previous step. The ideal choice of a threshold value between pores and solids depends on the transition characteristic of the gray values when crossing the boundary between pores and solids. Therefore, the first approach is to select the transition area and then analyze the histogram (GONZALEZ et al., 2002). In a first step, filters were used to identify regions of high intensity gradients, using filters to detect the edges (PRATT, 1991; GONZALEZ et al., 2002), such as Sobel and 
Laplacian, which are based on the first and second local derivatives of values and gray. The Sobel filter is sensitive to the transition zone, while the Laplacian filter distinguishes the beginning with positive values and the end with negative values.

Table 2: Characterization of chemical attributes and granulometry in areas under (Inceptisol) Cambissolo Háplico in Pinheiral (RJ).

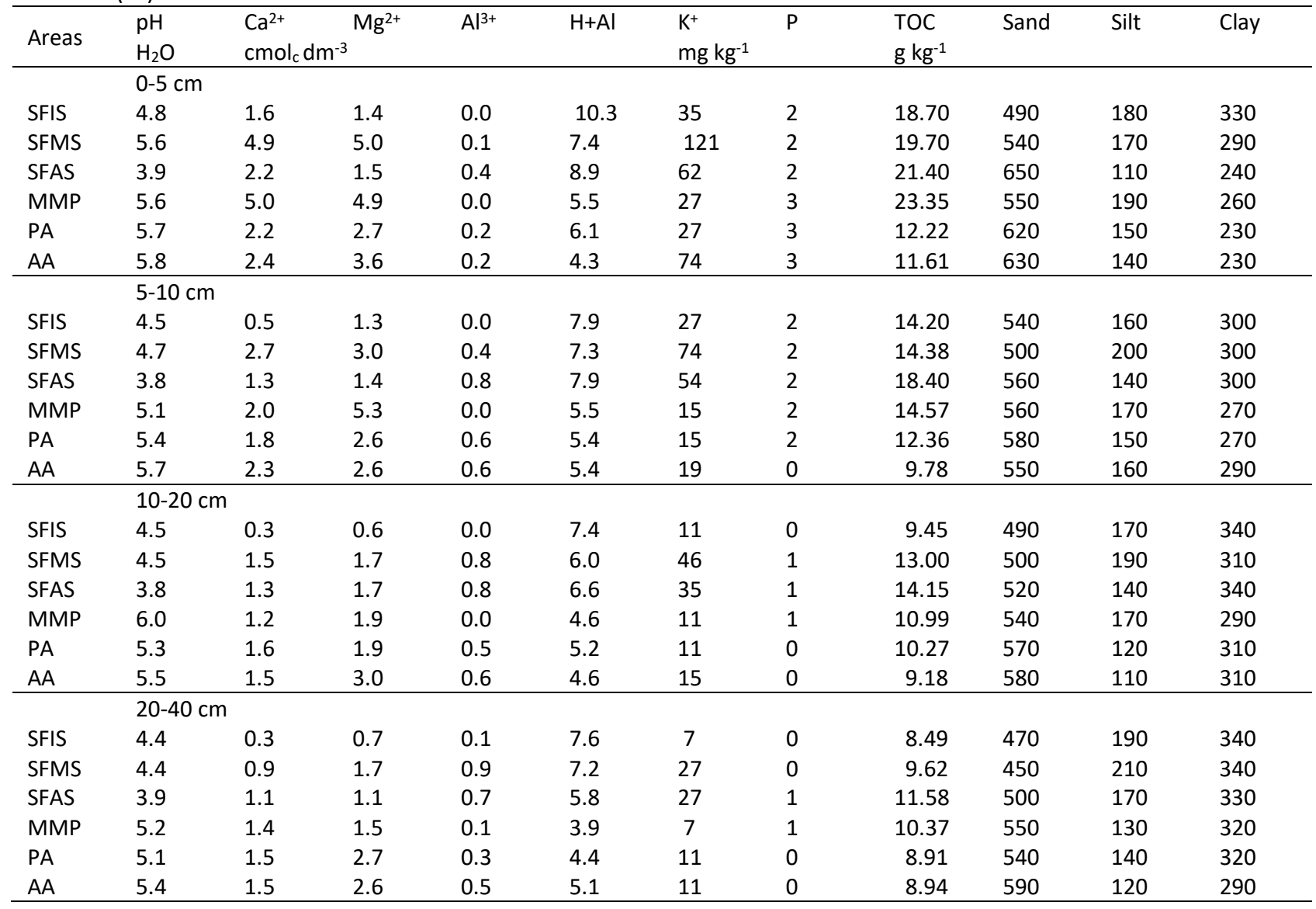

SFIS: Secondary Forest Initial Stage, SFMS: Secondary Forest Medium Stage, SFAS: Secondary Forest Advanced Stage, MMP: Managed Mixed, PA: Perennial Agriculture, AA: Annual Agriculture and TOC: Total organic carbon.

Source: Coutinho et al. (2017).

In the next step, the transition zones between pores and solids need to be identified, which leads to another threshold. The images generated with Sobel and Laplacian filter show unimodal distribution, which makes it difficult to separate the edges between pores and solids. The last step is to determine the $T_{\min }$ and $\mathrm{T}_{\max }$ threshold of the bi-level of the segmentation process introduced by Vogel et al. (1996) that can be based on the masks introduced previously, the Sobel and Laplacian filters. In the case of this study, the values of $T_{\min }$ and $T_{\max }$ found with the OriginPro software were used, as previously mentioned at the beginning of the entire process. Finally, grayscale images were generated, with the most adequate separation of pores and solids. Among this, at the end of the entire process, the variables porosity, soil density and aggregate density can be analyzed.

For the data related to aggregation and humic substances, in each layer, the evaluation of the normality of the residues (Lilliefors) and homoscedasticity of the error variances were made by the Cochran and Barttlet Test. Subsequently, the results were analyzed as a completely randomized design with five replications and six treatments, being subjected to variance analysis with application of the F Test and the 
average values compared to each other by the Scott-Knott Test, at $5 \%$ probability using the statistical program SAEG version 5.0.

\section{RESULTS AND DISCUSSION}

The results of organic carbon from humic fractions on SOM are shown in Table 3, with differences between the areas being observed. Among humic substances, the highest levels of carbon were observed in the humine fraction (HUM) (the most stable and recalcitrant fraction of SOM).

This pattern can be attributed to the accumulation of organic compounds with high chemical stability and molecular mass, resulting from the decomposition and humification of organic matter; and the strong interaction of these compounds with the mineral fraction of the soil, providing high resistance to microbial degradation (ORLOV, 1992; STEVENSON, 1994; EBELING et al., 2011). In terms of carbon sequestration, humine can be considered the most significant fraction as a reserve of organic carbon in the soil (FERREIRA et al., 2004).

Table 3: Organic carbon from humic fractions on SOM in areas under (Inceptisol) Cambissolo Háplico in Pinheiral (RJ).

\begin{tabular}{|c|c|c|c|c|}
\hline \multirow{2}{*}{ Areas } & $0-5 \mathrm{~cm}$ & $5-10 \mathrm{~cm}$ & $10-20 \mathrm{~cm}$ & $20-40 \mathrm{~cm}$ \\
\hline & \multicolumn{4}{|c|}{ HUM $\left(\mathrm{g} \mathrm{kg}^{-1}\right)$} \\
\hline SFIS & $12.72 \mathrm{~B}$ & $9.92 \mathrm{~A}$ & $5.00 \mathrm{C}$ & $5.26 \mathrm{C}$ \\
\hline SFMS & $12.32 \mathrm{~B}$ & $7.85 \mathrm{~B}$ & $8.14 \mathrm{~A}$ & $5.35 \mathrm{C}$ \\
\hline SFAS & $14.05 \mathrm{~A}$ & $9.83 \mathrm{~A}$ & $6.63 \mathrm{~B}$ & $5.24 \mathrm{C}$ \\
\hline MMP & $12.49 \mathrm{~B}$ & $9.94 \mathrm{~A}$ & $7.51 \mathrm{~A}$ & $5.73 \mathrm{~B}$ \\
\hline PA & $8.28 \mathrm{C}$ & $7.92 \mathrm{~B}$ & $5.51 \mathrm{C}$ & $5.07 \mathrm{C}$ \\
\hline \multirow[t]{2}{*}{$A A$} & $6.68 \mathrm{D}$ & $7.41 \mathrm{C}$ & $6.44 \mathrm{~B}$ & $6.63 \mathrm{~A}$ \\
\hline & \multicolumn{4}{|c|}{ HAF $\left(\mathrm{g} \mathrm{kg}^{-1}\right)$} \\
\hline SFIS & $1.07 \mathrm{E}$ & $1.68 \mathrm{~B}$ & $0.49 \mathrm{D}$ & $0.56 \mathrm{C}$ \\
\hline SFMS & $2.37 \mathrm{C}$ & $1.42 \mathrm{C}$ & $1.20 \mathrm{~B}$ & $0.49 \mathrm{C}$ \\
\hline SFAS & $2.70 \mathrm{~B}$ & $1.23 \mathrm{D}$ & $0.53 \mathrm{D}$ & $0.49 \mathrm{C}$ \\
\hline MMP & $2.83 \mathrm{~A}$ & $2.09 \mathrm{~A}$ & $1.35 \mathrm{~A}$ & $1.05 \mathrm{~A}$ \\
\hline PA & $1.67 \mathrm{D}$ & $1.68 \mathrm{~B}$ & $0.96 \mathrm{C}$ & $0.73 \mathrm{~B}$ \\
\hline \multirow[t]{2}{*}{$\mathrm{AA}$} & $0.99 \mathrm{E}$ & $0.50 \mathrm{E}$ & $0.67 \mathrm{D}$ & $0.52 \mathrm{C}$ \\
\hline & \multicolumn{4}{|c|}{ FAF $\left(\mathrm{g} \mathrm{kg}^{-1}\right)$} \\
\hline SFIS & $4.17 \mathrm{~A}$ & $3.08 \mathrm{~B}$ & $2.79 \mathrm{~A}$ & $2.30 \mathrm{~B}$ \\
\hline SFMS & $2.97 \mathrm{C}$ & $2.32 \mathrm{D}$ & $2.52 \mathrm{~B}$ & $2.23 \mathrm{~B}$ \\
\hline SFAS & $3.43 \mathrm{~B}$ & $3.63 \mathrm{~A}$ & $2.49 \mathrm{~B}$ & $3.38 \mathrm{~A}$ \\
\hline MMP & $3.54 \mathrm{~B}$ & $3.17 \mathrm{~B}$ & $2.24 \mathrm{C}$ & $2.11 \mathrm{~B}$ \\
\hline PA & $2.12 \mathrm{D}$ & $2.49 \mathrm{C}$ & $1.95 \mathrm{D}$ & $2.16 \mathrm{~B}$ \\
\hline AA & $1.67 \mathrm{E}$ & $1.63 \mathrm{E}$ & $1,54 \mathrm{E}$ & $1.42 \mathrm{C}$ \\
\hline
\end{tabular}

Averages followed by the same capital letter in the column do not differ the sample areas by the Scott-Knott Test $(p<0.05)$. SFIS: Secondary Forest Initial Stage, SFMS: Secondary Forest Medium Stage, SFAS: Secondary Forest Advanced Stage, MMP: Managed Mixed, PA: Perennial Agriculture, AA: Annual Agriculture, HUM: Humine fraction, HAF: Humic acid fraction and FAF: Fulvic acid fraction.

In the areas of SFAS $(0-5 \mathrm{~cm})$, SFIS, SFAS and MMP $(5-10 \mathrm{~cm})$, SFMS and MMP $(10-20 \mathrm{~cm})$ and AA $(20-$ $40 \mathrm{~cm}$ ) the highest levels of HUM (Table 3). Assessing the distribution of humic substances from SOM in areas under different forest cover in Seropédica (RJ), Giácomo et al. (2008), observed higher levels of HUM in secondary forest (SF), and lower in the areas of Mimosa caesa Ipinaefolia planting and Carapa guianenses planting.

Quantifying the litter input (LI) and the production of root biomass (RB) in the same areas of this study, Menezes et al. (2010) observed a tendency of increase in the total values of $\mathrm{LI}$ in the area under 
secondary forest advanced stage (SFAS) in comparison to the areas in initial and medium stage, and significantly higher levels of RB in SFAS. Later, Silva et al. (2012) also in Pinheiral (RJ) quantified higher values of total organic carbon (TOC) in the SFAS and pasture areas in the dry season. In the same location, Silva Neto et al. (2016) quantified higher values of carbon in the oxidizable fraction F3 in biogenic aggregates in the areas of SFAS and pasture. Coutinho et al. (2017) found that in the area with SFAS higher levels of TOC were observed.

High levels of TOC in forest areas may be associated with a greater amount of plant residues produced by different species, as well as with the efficient cycling of nutrients in these environments (TOLEDO et al., 2002). These factors can influence, in a greater stabilization of the organic matter to the mineral fraction of the soil. In natural environments, the formation of SOM humic fractions is linked to microbial activity, with the humification process, over time, being the final result of the microbial process (GAZOLLA et al., 2015).

Higher HUM values suggest greater water retention, improved soil aggregation (BENITES et al., 2003) and greater cation retention (SOUZA et al., 2003). The results of Menezes et al. (2010), Silva et al. (2012), Silva Neto et al. (2016) and Coutinho et al. (2017) are in agreement with HUM data in the area under SFAS $(0-10 \mathrm{~cm})$. In this environment, the absence of disturbance, the greater floristic diversity and the longer regeneration time may be some of the factors responsible for providing more favorable conditions to the stabilization and accumulation of HUM.

The humic acid (HAF) and fulvic acid (FAF) fractions submitted to polymerization and mineralization processes are less stable and show greater movement in the soil profile (FONTANA et al., 2006). This pattern is confirmed by the lower levels of carbon observed in these compartments (Table 3). Similar results were verified by Fernandes et al. (2017), when quantifying and comparing the carbon content of humic substances in aggregates formed by different pathways and plant coverings in Pinheiral (RJ).

As for HAF (moderately labile fraction of SOM), the highest concentrations of this fraction were found in the area under MMP in all layers (Table 3). Humic acids are considered markers of the humification process, and reflect both the condition of genesis and soil management (CANELLAS et al., 2003). In their studies, Giácomo et al. (2008), quantified in the layers of 0-5 and 20-40 cm, higher levels of HAF in the SF area, a divergent pattern from that observed in this study.

The HAF and HUM data in the area with MMP corroborate the pattern observed in the study by Silva et al. (2017). In this, the authors found that the highest values of these compartments were quantified, in general, in the areas of pasture and forest. The quality of the plant material, the contribution of grass roots and the non-revolving soil justified these results.

The results in MMP show the beneficial effect provided by grasses (C4 cycle plants) that tend to contribute with a greater carbon supply to the soil (BARRETO et al., 2006) via surface deposition or root system renewal. Indicating that grasses are more efficient in increasing the levels of HUM and HAF, mainly in depth, through the continuous addition of organic material with a high $\mathrm{C} / \mathrm{N}$ ratio. Management systems that 
insert grasses, especially brachiariae, are more effective to promoting the formation and stabilization of carbon in the humine and humic acid fractions, probably due to the slower rate of decomposition of organic waste (LOSS et al., 2013).

Regarding the FAF, in the areas of SFIS $(0-5$ and $10-20 \mathrm{~cm})$ and SFAS $(5-10$ and $20-40 \mathrm{~cm})$ the highest carbon content was quantified. FAF is more soluble and labile, so its dynamics of formation and decomposition are more accelerated compared to other humic fractions (FONTANA et al., 2006). The high content of FAF in the area with SFAS may be associated with the characteristics inherent to the forest fragment, favoring the formation and accumulation of this more mobile SOM fraction.

In the area of SF in Seropédica (RJ), Giácomo et al. (2008), found higher levels of FAF. Evaluating TOC in pasture areas and forest fragments of Atlantic Forest with different succession stages, Guareschi et al. (2014), found higher values of this attribute in the forest area with initial stage compared to the pasture area in the $10-40 \mathrm{~cm}$ layer. According to the authors, the results can be justified due to the greater and constant deposition of plant residues in the soil, as well as to the carbon contribution of both plants of C3 cycle (forest) and C4 cycle (residual carbon of the pasture area that preceded the forest). The results of TOC partially corroborate those of FAF in the area under SFIS $(0-5$ and $10-20 \mathrm{~cm})$ of this study.

In general, in the areas of PA and AA, the lowest values of HUM, HAF and FAF were quantified (Table 3). This pattern demonstrates the negative impact that occurred on the soil after converting native forests to agricultural areas, which may cause less input of organic material and nutrient cycling in these environments compared to forest environments (SILVA et al., 2012). Contributing to the reduction of the carbon content in humic substances. In the dry season, Silva et al. (2012), found reductions of 47 and $32 \%$ in carbon from microbial biomass in areas of perennial and annual agriculture, respectively, compared to forest areas. Thus, reinforcing the harmful effect of management in these agricultural areas on other fractions of the SOM.

Figure 2 shows the results of the distribution of stable aggregates in size classes, with the verification that most of the aggregates have a size $\geq 2.0 \mathrm{~mm}$, falling into the class of large macroaggregates (8.0-2.0 $\mathrm{mm})$. In the subsequent classes, the aggregate mass followed the same pattern observed. Aggregates with a higher degree of stability contribute to the improvement of porosity, and consequently, greater infiltration and resistance to erosion (MATOS et al., 2008; COUTINHO et al., 2010).

Such results may be due to the greater contribution and accumulation of litter or organic residues on the soil surface and the organic material added inside the profile via root system renewal, associated with the absence or minimal anthropic disturbance, thus favoring the maintenance of organic matter in the system. SOM has a direct influence on the aggregates formation and stabilization due to its diversified molecular structure and the decomposition rates of its different fractions in the soil (SCHILLER et al., 2018).

In the class of large macroaggregates in the areas of SFIS, SFMS, SFAS and MMP $(0-5 \mathrm{~cm})$ and SFIS, SFMS, MMP and PA $(5-10 \mathrm{~cm})$ the highest aggregate mass values were quantified (Figure 2). 
A
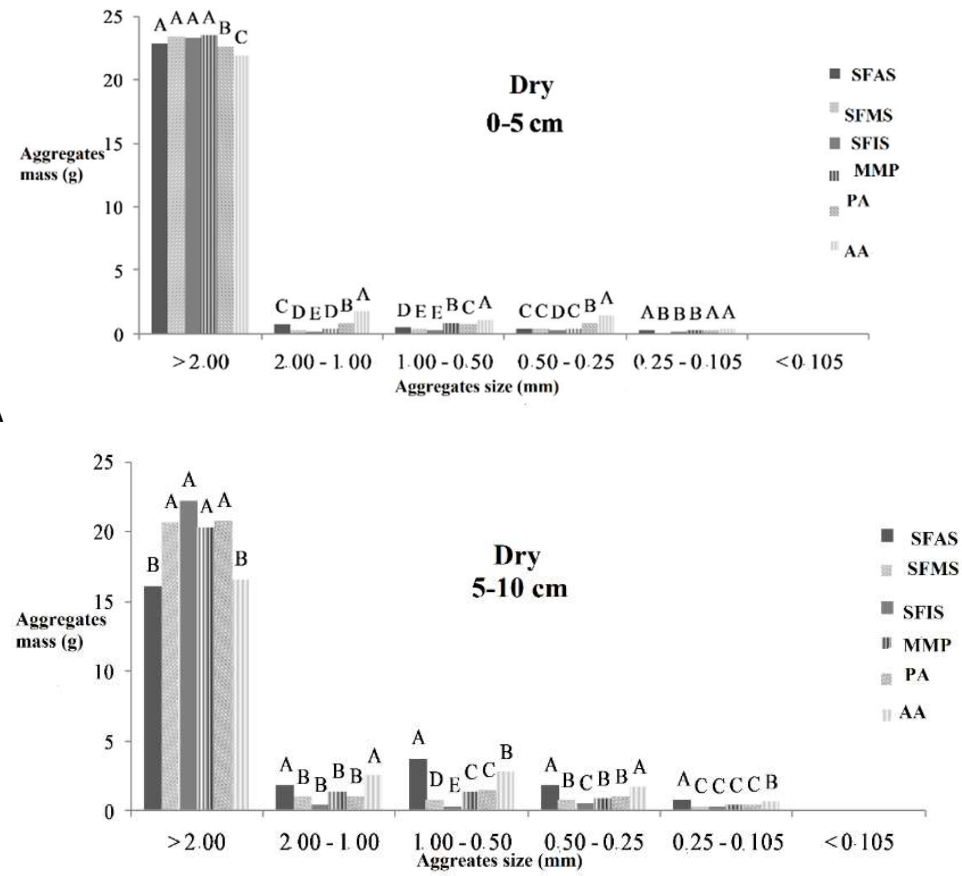

B

Figure 2: Distribution of water-stable aggregates by diameter classes in areas under Cambissolo Háplico in Pinheiral $(\mathrm{RJ})$ in layers 0-5 (A) and 5-10 cm (B). Averages followed by the same capital letter do not differ the sample areas by the Scott-Knott Test $(p<0.05)$. SFIS: Secondary Forest Initial Stage, SFMS: Secondary Forest Medium Stage, SFAS:

Secondary Forest Advanced Stage, MMP: Managed Mixed Pasture, PA: Perennial Agriculture and AA: Annual Agriculture.

It appears that the more stable the aggregates determined by wet sieving in the class of large macroaggregates are, the greater the mass value, and consequently the higher the values of the weighted and geometric mean diameter (WMD and GMD, respectively) of the soil aggregation. Pattern observed by Coutinho et al. (2017) when assessing the stability of aggregates, in areas under different vegetation cover and forms of use. The authors quantified higher values of WMD and GMD in the forest and pasture areas, and lower in the area under annual agriculture, corroborating the mass data of large macroaggregates in this study.

Higher WMD values of the aggregates were found by Guareschi et al. (2014) in the area under SFIS compared to the area with SFAS, while the areas with SFMS and pasture showed intermediate results for these areas. Silva Neto et al. (2016) found that in the physicogenic and intermediate aggregates in the areas of SFMS, SFIS and MMP, and in biogenic aggregates in the area under SFIS, the highest values of WMD were observed. Silva et al. (2017) quantified higher WMD values in the pasture system and forest areas. High mass values of large macroaggregates were observed by Fernandes et al. (2017) in the areas of SFMS and SFIS, and minors in the area with SFAS.

Assessing the levels of soil protein related to glomalin (SPRG) in the same areas of the study, Silva et al. (2016) found under SFAS and pasture system higher concentrations of SPRG-easily extractable in relation to agricultural areas (dry period) and for the SPRG-total in the area under pasture, the highest values were observed, with significant reductions in the area of perennial agriculture (dry period). The nature of glomalin (heat resistance, insolubility and hydrophobicity) guarantees its cementing function, and is usually used in 
aggregation studies due to the strong correlation with aggregate stability (PENG et al., 2013; NOBRE et al., 2015). Such results are in agreement with the large macroaggregation mass data $(0-5 \mathrm{~cm})$ from the present study.

In the class of small macroaggregates $(2.0-1.0 ; 1.0-0.50$ and $0.50-0.25 \mathrm{~mm})$, the highest mass values were found in the areas of AA $(0-5 \mathrm{~cm})$ and SFAS and AA $(5-10 \mathrm{~cm})$. For the microaggregates class $(0.25-0.105$ $\mathrm{mm})$, in the areas of SFAS, PA and AA $(0-5 \mathrm{~cm})$ and SFAS $(5-10 \mathrm{~cm})$ the highest mass values were quantified (Figure 2). Regarding the formation of aggregates, the micro are joined by persistent organic compounds and polymeric substances that in association with materials such as roots and hyphae form and stabilize the small and large macroaggregates (STEVENSON, 1994; LOSS et al., 2020).

In the 2.0-0.50 $\mathrm{mm}$ aggregate class in areas of secondary forest in advanced and intermediate succession stages, Silva et al. (2017), quantified higher levels of SPRG-total. The levels of SPRG-total in these areas may be related to the protein accumulation over time, as it presents high stability in the soil.

Macroaggregates (large) and microaggregates are more sensitive to land use or management (LOSS et al., 2020). In the SFAS area, a larger mass of smaller aggregates was observed, probably due to the longer time of land use associated with higher levels of SOM in a higher degree of humification, favoring the maintenance and stabilization of microaggregates (FERNANDES et al., 2017), as seen in the SFAS area (0-10 $\mathrm{cm})$. While the activity of the root system may have benefited the formation of intermediate aggregates (small macroaggregates) in the areas of AA $(0-10 \mathrm{~cm})$, and large in the areas of SFIS, SFMS and MMP (0-10 $\mathrm{cm})$.

The data for porosity and aggregates density variables obtained using the computed tomography (CT) technique are presented in Figures 3 and 4. In the SFIS and SFAS areas, variations in the percentage of inter-aggregates pores were observed approximately from slides 253 and 316, in due order. At these points, there was an increase in porosity and a reduction in soil density (SD) (Figure 3).

In these areas, Coutinho et al. (2017), found an increase in the values of macroporosity (1.1 and 1.7 $\mathrm{m}^{3} \mathrm{~m}^{-3}$ under SFIS and SFAS, respectively) and decreased SD (1.16 and $0.96 \mathrm{Mg} \mathrm{m}^{-3}$, in SFIS and SFAS, in that order) in the 5-10 cm layer, corroborating the results verified in the study. Guareschi et al. (2014), observed higher values of SD in the areas of SFIS and pasture system, with greater total pore volume under SFAS in the 0-10 cm layer.

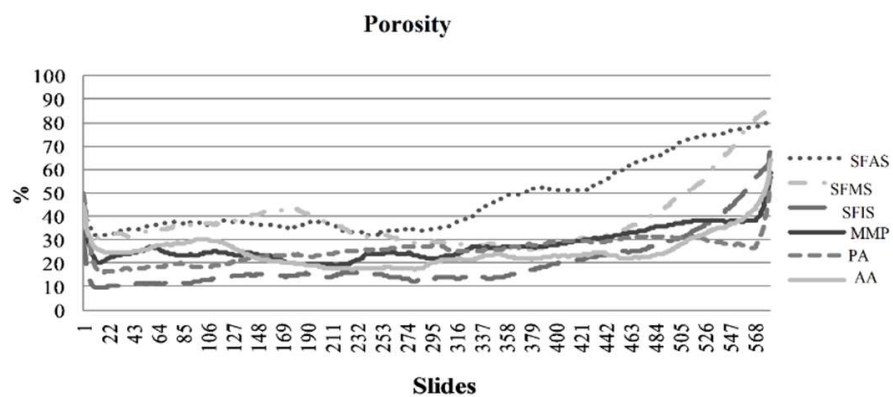

Figure 3: Porosity variable obtained through X-ray computed tomography analysis in areas under (Inceptisol) Cambisolo Háplico in Pinheiral (RJ). SFIS: Secondary Forest Initial Stage, SFMS: Secondary Forest Medium Stage, SFAS: Secondary Forest Advanced Stage, MMP: Managed Mixed Pasture, PA: Perennial Agriculture and AA: Annual Agriculture. 
A possible explanation for the pattern found in this study for the porosity variable (Figure 3 ), may be due to the effect of the roots mechanical action that favors the accumulation of organic material and, consequently, an increase in soil aggregation and porosity, thus decreasing the SD. Petrovic et al. (1982) demonstrated by means of $\mathrm{X}$-ray techniques that mineral particles, aggregates, soil density and roots are attributes that directly influence macroporosity.

For the aggregates density, in the SFIS, SFMS, SFAS and MMP areas, no variations were quantified in the Hounsfield unit (HU) (Figure 4). This variable is evaluated from the quantification of intra-aggregates voids, micropores and WMD by means of $\mathrm{CT}$. The HU is the number used to describe the attenuation of the X-rays of each voxel in a 3D model image. CT studies by Rachman et al. (2005) in lowa and Missouri in the USA, demonstrated that grasses, for example, positively affect soil porosity and macroporosity.

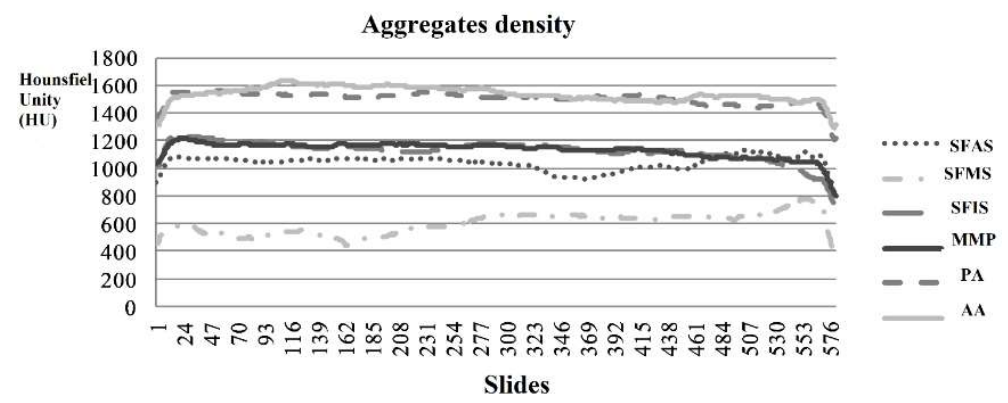

Figure 4: Aggregates density variable obtained through X-ray computed tomography analysis in areas under (Inceptisol) Cambisolo Háplico in Pinheiral (RJ).

SFIS: Secondary Forest Initial Stage, SFMS: Secondary Forest Medium Stage, SFAS: Secondary Forest Advanced Stage, MMP: Managed Mixed Pasture, PA: Perennial Agriculture and AA: Annual Agriculture.

In the $0-20 \mathrm{~cm}$ layer, Coutinho et al. (2017) found similar microporosity values between the areas of SFIS and SFMS, and SFAS, MMP, PA and AA. In addition, WMD values without difference for the areas of SFIS, SFMS, SFAS and MMP in the 0-5 cm layer. Demonstrated that there is no variation in the stability of aggregates at this depth. The pattern observed for the aggregate density variable in forest and pasture areas (Figure 4), can be attributed to the edaphic characteristics discussed above.

In the SFMS area, a hyperbolic pattern was observed in the results, starting from slides 169 and 369, with a decrease and an increase in porosity, respectively (Figure 3). Coutinho et al. (2017) also observed such peculiarity by decreasing the values of SD (1.23 to $\left.1.14 \mathrm{Mg} \mathrm{m}^{-3}\right)$ and macroporosity ( 1.3 to $0.3 \mathrm{~m}^{3} \mathrm{~m}^{-3}$ ) between the 0-5 and 5-10 cm layers. With subsequent increase in the values of these attributes in the underlying layer (1.18 $\mathrm{Mg} \mathrm{m}^{-3}$ and $0.9 \mathrm{~m}^{3} \mathrm{~m}^{-3}$, in due order). The results found in SFMS (Figure 3), may be due to the history of agricultural crops carried out in the area before the forest recovery process.

In the PA area, there was a small increase in porosity (gradual decrease in SD) (Figure 3). Despite the results found in this area, studies have shown clear links to increased soil density and resistance, in response to inadequate soil management practices (ATKINSON et al., 2009). Pattern observed in the AA area, with a decrease in porosity (increase in SD) approximately from slide 106 (Figure 3). Such data are similar to those verified by Coutinho et al. (2017), with higher SD in these agricultural production environments. 
In the areas of PA and $\mathrm{AA}$, variations in the $\mathrm{HU}$ scale for the aggregates' density were not quantified

(Figure 4). Pattern concordant to observed by Coutinho et al. (2017) for microporosity, suggesting that, in depth, the greatest variations caused by the management of the edaphic structure occur inter-aggregates and not intra-aggregates.

\section{CONCLUSIONS}

Humic substances and aggregate classes below $2.0 \mathrm{~mm}$ were the attributes most influenced by the forms of use and/or vegetation cover. The computed tomography technique proved to be efficient in the measurement of the edaphic attributes porosity and aggregates density, aiding in the characterization and separation of the different environments.

The most advanced stage of forest succession benefited the stabilization and accumulation of carbon in the most stable and recalcitrant humic fraction on SOM (humine), contributing to the formation of microaggregates. The management adopted in the pasture area associated with the physiological characteristics of the grasses, promoted an increase in the carbon content in the moderately labile (humic acid) and stable (humine) humic fractions on SOM, mainly in depth. The removal of the forest, for subsequent implantation of agricultural areas, disfavored the maintenance of carbon in humic substances, and negatively affected porosity, aggregates density and soil macroaggregation.

ACKNOWLEDGEMENTS: National Council for Scientific and Technological (CNPq).

\section{REFERENCES}

ATKINSON, B. S.; SPARKES, D. L.; MOONEY, S. J.. The impact of soil structure on the establishment of winter wheat (Triticum aestivum). Europe Journal Agronomy, v.30, p.243257, 2009. DOI: https://doi.org/10.1016/j.eja.2008.12.002

BARRETO, A. C.; LIMA, F. H. S.; FREIRE, M. B. G. S.; ARAÚJO, Q. R.; FREIRE, R. A.. Características químicas e físicas de um solo sob floresta, sistema agroflorestal e pastagem no sul da Bahia. Caatinga, v.19, p.415-425, 2006.

BENITES, V. M.; MADARI, B.; MACHADO, P. L. O. A.. Extração e fracionamento quantitativo de substâncias húmicas do solo: um procedimento simplificado de baixo custo. Rio de Janeiro: Embrapa Solos, 2003.

CONAMA. Conselho Nacional do Meio Ambiente. Resolução n. 6, de 4 de maio de 1994. Brasília: CONAMA, 1994.

CANELLAS, L. P.; VELLOSO, A. C. X.; MARCIANO, C. R.; RAMALHO, J. F. G. P.; RUMJANEK, V. M.; REZENDE, C. E.; SANTOS, G. A.. Propriedades químicas de um Cambissolo cultivado com cana-de açúcar, com preservação do palhiço e adição de vinhaça por longo tempo. Revista Brasileira de Ciência do Solo, v.27, p.935-944, 2003.

COSTA JUNIOR, C.; PICCOLO, M. C.; SIQUEIRA NETO, M.; CAMARGO, P. B.; CERRI, C. C.; BERNOUX, M.. Carbono em agregados do solo sob vegetação nativa, pastagem $\mathrm{e}$ sistemas agrícolas no bioma Cerrado. Revista Brasileira de Ciência do Solo, v.36, p.1311-1321, 2012.

COUTINHO, F. S.; LOSS, A.; PEREIRA, M. G.; RODRIGUES JUNIOR, D. J.; TORRES, J. L. R.. Estabilidade de agregados e distribuição do carbono em Lotossolo sob sistema plantio direto em Uberaba, Minas Gerais. Comunicata Scientiae, v.1, n.2, p.100-105, 2010.

COUTINHO, F. S.; PEREIRA, M. G.; MENEZES, C. E. G.; GUARESCHI, R. F.; ASSUNÇÃO, A. A.. Atributos edáficos em áreas de agricultura, pastegem e três estágios sucesssionais de floresta. Floresta e Ambiente, v.24, e00091914, p.1-11, 2017. DOI: https://doi.org/10.1590/2179-8087.091914

DENEF, K.; ZOTARELLI, L.; BODDEY, R. M.; SIX, J..

Microaggregate-associated carbon as a diagnostic fraction for management-induced changes in soil organic carbon in two Oxisols. Soil Biology and Biochemistry, v.39, p.11651172, 2007. DOI: https://doi.org/10.1016/j.soilbio.2006.12.024

EBELING, A. G.; ANJOS, L. H. C.; PEREIRA, M. G.; PINHEIRO, E. F. M.; VALLADARES, G. S.. Substâncias húmicas e relação com atributos edáficos. Bragantia, v.70, n.1, p.157-165, 2011.

ELLIOT, T. R.; HECK, R. J.. A comparison of 2D vs. 3D 
thresholding of X-ray CT imagery. Canadian Journal Soil Science, v.87, p.405-412, 2007. DOI: https://doi.org/10.4141/CJSS06017

ELLIOT, T. R.; REYNOLDS, W. D.; HECK, R. J.. Use of existing pore models and $\mathrm{X}$-ray computed tomography to predict saturated soil hydraulic conductivity. Geoderma, v.156, p.133-142, 2010. DOI:

https://doi.org/10.1016/j.geoderma.2010.02.010

FERNANDES, J. C. F.; PEREIRA, M. G.; SILVA NETO, E. C.; CORREA NETO, T. A.. Characterization of biogenic, intermediate and physicogenic soil aggregates of areas in the Brazilian Atlantic Forest. Revista Caatinga, v.30, n.1, p.59-67, 2017. DOI: https://doi.org/10.1590/198321252017v30n107rc

FERREIRA, J. A.; SIMÕES, M. L.; MILORE, D. M. B. P.; MARTINNETO, L.; HAYES, M. H. B.. Caracterização Espectroscópica da Matéria Orgânica do Solo. Embrapa São Carlos, 2004.

FONTANA, A.; PEREIRA, M. G.; LOSS, A.; CUNHA, T. J. F.; SALTON, J. C.. Atributos de fertilidade e frações húmicas de um Latossolo Vermelho no Cerrado. Pesquisa Agropecuária Brasileira, v.41, n.5, p.847-853, 2006.

SOS; INPE. Fundação Sos Mata Atlântica. Instituto Nacional De Pesquisas Espaciais. Atlas dos Remanescentes Florestais da Mata Atlântica: Período 2017-2018. São Paulo: SOS, 2020.

GAZOLLA, P. R.; GUARESCHI, R. F.; PERIN, A.; PEREIRA, M. G.; ROSSI, C. Q.. Frações da matéria orgânica do solo sob pastagem, sistema plantio direto e integração lavourapecuária. Semina: Ciências Agrárias, v.36, p.693-704, 2015. DOI: https://doi.org/10.5433/1679-0359.2015v36n2p693

GE HEALTHCARE. Explore locus user guide. Technical Publication Direction 2394683 Revision 1a. Chicago: GE HEALTHCARE, 2005.

GIÁCOMO, R. G.; PEREIRA, M. G.; BALIEIRO, F. C.. Estoques de carbono e nitrogênio e distribuição das frações húmicas no solo sob diferentes coberturas florestais. Revista Brasileira de Ciências Agrárias, v.3, n.1, p.42-48, 2008.

GONZALEZ, R.; WOODS, R.. Digital image processing. Upper Saddle Creek: Prentice-Hall, 2002.

GUARESCHI, R. F.; PEREIRA, M. G.; MENEZES, C. E. G.; ANJOS, L. H. C.; CORREIA, M. E. F.. Atributos químicos e físicos do solo sob pastagem e estádios sucessionais de floresta estacional. Revista de la Facultad de Agronomia, v.113, n.1, p.47-56, 2014.

HOUNSFIELD, G. N.. Computerized transverse axial scanning (tomography). Description of system. The British Journal Radiology, v.46, p.1016-1022, 1973.

LOSS, A.; PEREIRA, M. G.; PERIN, A.; BEUTLER, S. J.; ANJOS, L. $H$. C.. Oxidizable carbon and humic substances in rotation systems with brachiaria/livestock and pearl millet/no livestock in the Brazilian Cerrado. Spanish Journal of Agricultural Research, v.11, p.217-231, 2013. DOI: http://dx.doi.org/10.5424/sjar/2013111-3416
LOSS, A.; FERREIRA, G. W.; COMIN, J. J.; PEREIRA, M. G.; FREO, V. A.; PICCOLO, M. C.; BRUNETTO, G.. Carbono orgânico total e oxidável em agregados de um Argissolo adubado com dejetos suínos. Cienc. Suelo, v.38, n.1, p.1220, 2020.

MATOS, E. S.; MENDONCA, E. S.; LEITE, L. F. C.; GALVÃO, J. C. C.. Estabilidade de agregados e distribuição de carbono e nutrientes em Argissolo sob adubação orgânica e mineral. Pesquisa Agropecuária Brasileira, v.43, p.1221-1230, 2008. DOI: https://doi.org/10.1590/S0100-204X2008000900017

MENEZES, C. E. G.; PEREIRA, M. G.; CORREIA, M. E. F.; ANJOS, L. H. C.; PAULA, R. R.; SOUZA, M. E.. Aporte e decomposição da serapilheira e produção de biomassa radicular em florestas com diferentes estágios sucessionais em Pinheiral, RJ. Ci. Flor., v.20, p.439-452, 2010. DOI: https://doi.org/10.5902/198050982059

MENEZES, C. E. G.. Integridade de paisagem, manejo e atributos do solo no Médio Vale do Paraíba do Sul, Pinheiral-RJ. Tese (Doutorado em Agronomia - Ciência do Solo), Universidade Federal Rural do Rio de Janeiro, Seropédica, 2008.

NOBRE, C. P.; LÁZARO, M. L.; ESPIRITO SANTO, M. M.; PEREIRA, M. G.; BERBARA, R. L.. Agregação, glomalina e carbono orgânico na chapada do Araripe, Ceará, Brasil. Caatinga, v.28, p.138-47, 2015.

ORIGINLAB CORPORATION. Origin Lab Data Analysis and Graphing Software: OriginPro Version 7.5. Northampton: ORIGINLAB CORPORATION, 2004.

ORLOV, D. S.. Humic substances of soils and general theory of humification. Moscow: University Press, 1992.

PAULA, R. R.; PEREIRA, M. G.; MACHADO, D. L.. Atributos químicos e matéria orgânica em complexos florestais periodicamente inundados na Restinga da Marambaia (RJ). Ciência Florestal, v.23, p.529-538, 2013. DOI: https://doi.org/10.5902/1980509812337

PAVLIDIS, T.; LIOW, Y.. Integrating region growing and edge detection. IEEE Transactions on Pattern Analysis and Machine Intelligence, v.12, n.3, p.225-233, 1990. DOI: https://doi.org/10.1109/34.49050

PENG, S.; GUO, T.; LIU, G.. The effects of arbuscu-lar mycorrhizal hyphal networks on soil aggregations of purple soil in sothwest China. Soil Biology Bio-chemistry, v.57, n.2, p.411 417, 2013. DOI: https://doi.org/10.1016/j.soilbio.2012.10.026

PETROVIC, A. M.; SIEBERT, J. E.; RIEKE, P. E.. Soil bulk density analysis in three dimensions by computed tomographic scanning. Soil Science Society of America Journal, v.46: p.445-450, 1982. DOI: https://doi.org/10.2136/sssaj1982.03615995004600030001 $\underline{x}$

PRATT, W.. Digital image processing. New York: Wiley \& Sons, 1991.

RACHMAN, A.; ANDERSON, S. H.; GANTZER, C. J.. Computedtomographic measurement of soil macroporosity 
parameters as affected by stiff-stemmed grass hedges. Journal Soil Science Society of America, v.69, p.1609-1616, 2005. DOI: https://doi.org/10.2136/sssaj2004.0312

RAJAB, M. I.; ALAWI, M. H.; SAIF, M. A.. Application of Image Processing to Measure Road Distresses, WSEAS Transactions on Information Science \& Applications, v.5, n.1, 2008.

RICHARD, A.; FILHO, J. T.; BRITO, O. R.; ILNILLO, R. F.; FERREIRA, R.. Compactação do solo: causas e efeito. Semina: Ciências Agrárias, v.26, n.3, p.321-344, 2005.

SANTOS, H. G.; JACOMINE, P. K. T.; ANJOS, L. H. C.; OLIVEIRA, V. A.; LUMBRERAS, J. F.; COELHO, M. R.; ALMEIDA, J. A.; ARAÚJO FILHO, J. C.; OLIVEIRA, J. B.; CUNHA, T. J. F.. Sistema Brasileiro de Classificação de Solos. 5 ed. Brasília: Embrapa, 2018.

SCHILLER, A. P.; MANFRIN, J.; ECKHARDT, D. C. S.; SEIDEL, E. P.; LANA, M. C.; GONÇALVES, J. R. A. C.; SAMPAIO, M. C.; REGO, C. A. R. M.. Stability of Aggregates and the Processes that Help in Their Formation and Stabilization. International Journal of Plant \& Soil Science, v.22, n.5, p.1-14, 2018. DOI: https://doi.org/10.9734/IJPSS/2018/41056

SCHLUTER, S.; WELLER, U.; VOGEL, H. J.. Segmentation of Xray microtomography images of soil gradient masks.

Computers \& Geosciences, v.36, p.1246-1251, 2010. DOI: https://doi.org/10.1016/j.cageo.2010.02.007

SILVA, C. F.; PEREIRA, M. G.; FERNANDES, J. C. F.; FONSECA JÚNIOR, A. M.; GOMES, J. H. G.; MENEZES, C. E. G.. Soil organic matter fractions, chemical attributes and aggregation under forestry and agricultural systems. Comunicata Scientiae, v.8, n.3, p.459-468, 2017. DOI: https://doi.org/10.14295/CS.v8i3.1788

SILVA, C. F.; PEREIRA, M. G.; MIGUEL, D. L.; FERNADES, J. C. F.; LOSS, A.; MENEZES, C. E. G.; SILVA, E. M. R.. Carbono orgânico total, biomassa microbiana e atividade enzimática do solo de áreas agrícolas, florestais e pastagem no médio vale do paraíba do sul (RJ). Revista Brasileira de Ciência do Solo, v.36, p.1680- 689, 2012. DOI:

https://doi.org/10.1590/S0100-06832012000600002

SILVA, C. F.; PEREIRA, M. G.; SANTOS, V. L.; MIGUEL, D. L.; SILVA, E. M. R.. Fungos micorrízicos arbusculares: Composição, comprimento de micélio extra radicular e glomalina em áreas de Mata Atlântica, RJ. Ciência Florestal, v.26, n.2, p.419-433, 2016. DOI:

https://doi.org/10.5902/1980509822743

SILVA NETO, E. C.; PEREIRA, M. G.; FERNANDES, J. C. F.; CORRÊA NETO, T. A.. Aggregate formation and soil organic matter under different vegetation types in Atlantic Forest from Southeastern Brazil. Semina: Ciência agrárias, v.37, n.6, p.3927-3940, 2016. DOI: https://doi.org/10.5433/1679$\underline{0359.2016 v 37 n 6 p 3927}$
SOUZA, W. J. O.; MELO, W. J.. Matéria orgânica em um Latossolo submetido a diferentes sistemas de produção de milho. Revista Brasileira de Ciência do Solo, v.27, p.11131122, 2003.

STEVENSON, F. J.. Humus chemistry. Genesis, composition, reaction. 2 ed. New York: John Wiley, 1994.

SWIFT, R. S.. Organic matter characterization. In: Methods of soil analysis (Sparks DL, Page AL, Helmke PA, Loeppert RH, Soltanpour PN, Tabatabai MA, Johnston CT, Sumner ME, eds) Soil Sci Soc Am and Am Soc Agron. Madison, 1996. p.1011-1020.

TAINA, A. R.; HECK, R. J.; ELLIOT, T. R.. Application of X-ray computed tomography to soil science: A literature review. Canadian Journal of Soil Science, v.88 p.1-20, 2007. DOI: https://doi.org/10.4141/CJSS06027

TEIXEIRA, P. C.; DONAGEMMA, G. K.; FONTANA, A.; TEIXEIRA, W. G.. Manual de Métodos de Análise de Solos. Rio de Janeiro: Embrapa, v.2, p. 573, 2017.

TOLEDO, L. O.; PEREIRA, M. G.; MENEZES, C. E. G.. Produção de serapilheira e transferência de nutrientes em florestas secundárias localizadas na região de Pinheiral, RJ. Ci. Flor., v.12, p.9-16, 2002.

TOLLNER, E. W.. X-Ray computed tomography applications in soil ecology studies. Agriculture, Ecosystem and Environment, v.34, p.251-260, 1991. DOI: https://doi.org/10.1016/0167-8809(91)90112-B

VOGEL, H. J.; KRETZSCHMAR, A.. Topological characterization of pore space in soil sample preparation and digital imageprocessing. Geoderma, v.73, n.1, p.23-38, 1996. DOI: https://doi.org/10.1016/0016-7061(96)00043-2

WARNER, G. S.; NIEBER, J. L.; MOORES, I. D.; GEISE, R. A.. Characterizing macropores in soil by computer tomography. Soil Science society of America Journal, v.53, p.653-660, 1989. DOI: https://doi.org/10.2136/sssaj1989.03615995005300030001 $\underline{x}$

YEOMANS, J. C.; BREMNER, J. M.. A rapid and precise method for routine determination of organic carbon in soil. Communications Soil Science and Plant Analysis, v.19, p.1467-1476, 1988. DOI: https://doi.org/10.1080/00103628809368027

YOODER, R. E.. A direct method of aggregate analysis of soil and a study of the physical nature of erosion losses. Journal of the American Society of Agronomy, v.28, p.337-351, 1936. DOI: https://doi.org/10.2134/agronj1936.0002196200280005000 $\underline{1 x}$

A CBPC - Companhia Brasileira de Produção Científica (CNPJ: 11.221.422/0001-03) detém os direitos materiais desta publicação. Os direitos referem-se à publicação do trabalho em qualquer parte do mundo, incluindo os direitos às renovações, expansões e disseminações da contribuição, bem como outros direitos subsidiários. Todos os trabalhos publicados eletronicamente poderão posteriormente ser publicados em coletâneas impressas sob coordenação da Sustenere Publishing, da Companhia Brasileira de Produção Científica e seus parceiros autorizados. Os (as) autores (as) preservam os direitos autorais, mas não têm permissão para a publicação da contribuição em outro meio, impresso ou digital, em português ou em tradução. 